\title{
Preliminary assessment of the anti-inflammatory and analgesic effects of methanol leaf extract of Cussonia barteri (Araliaceae) in rodents
}

\author{
IGHODARO IGBE*, OSAZE EDOSUYI, AGBONLAHOR OKHUAROBO, ADARKI PONGRI, \\ NKECHI MADUAKO, ISAAC EHIMEN
}

Department of Pharmacology and Toxicology

Faculty of Pharmacy

University of Benin

Benin City, Nigeria

*corresponding author: igbe.ighodaro@uniben.edu

\section{Summary}

Introduction: Potato (Solanum tuberosum L.) is an important vegetable crop in Syria. Potato tuber moth Cussonia barteri is a small tree that grows in the sub-Saharan part of Africa. Various parts of the plant are used for the treatment of a variety of ailments in ethno-medicine.

Objective: To evaluate the anti-inflammatory and analgesic effect of the methanol leaf extract of Cussonia barteri.

Material and methods: The leaves were air-dried, powdered and repeatedly extracted with methanol using a Soxhlet apparatus. The resulting methanol extract $(100,200$ and $400 \mathrm{mg} / \mathrm{kg})$ was evaluated for antiinflammatory activity using carrageenan-induced paw oedema, xylene-induced ear oedema and formalininduced arthritis tests. Analgesic effect was evaluated using acetic acid-induced mouse writhing, hot plate and tail flick tests.

Results: All doses of the extract significantly $(p<0.05)$ reduced carrageenan-induced paw oedema, however the $400 \mathrm{mg} / \mathrm{kg}$ dose gave a sustained effect. The extract significantly inhibited xylene induced ear oedema at all doses. There were no significant $(p>0.05)$ reductions in paw swellings due to formalin. In the acetic acid induced writhing test, the extract significantly $(p<0.05)$ decreased writhing at $400 \mathrm{mg} / \mathrm{kg}$ only. Reaction times were not significantly different from the control in the hot plate and tail flick tests.

Conclusion: This study has shown that the methanol extract possesses acute anti-inflammatory and peripherally mediated analgesic effects. 
Key words: Cussonia barteri, methanol leaf extract, anti-inflammatory activity, analgesic activity

Słowa kluczowe: Cussonia barteri, metanolowy wyciag z liści, działanie przeciwzapalne, działanie przeciwbólowe

\section{INTRODUCTION}

Inflammation is a complex, adaptive response that is usually activated by harmful stimuli, such as infection, irritants and tissue malfunction or injury [1]. Inflammation is characterized by fundamental signs which includes: redness (rubor), swelling (tumour), heat (calor), pain (dolor) and loss of function (functio laesa) [2]. Inflammation could be acute or chronic and involves cellular and molecular events. It is now understood that virtually all pathological conditions have an inflammatory component [3]. Algesia or pain is a component of the inflammatory process and is a result of the effects of inflammatory mediators on sensory nerves (nociceptors) [2]. Consequently, anti-inflammatory studies are usually carried out concurrently with analgesic studies $[4,5]$. The currently available anti-inflammatory agents have side effects that limit their usage, thus leading to increased use of alternative therapies, especially herbal medicines in developing societies [3]. These inadequacies associated with antiinflammatory drugs underscore the need to search for newer agents and medicinal plants have been cardinal to this search [6]. Several medicinal plants and its isolated compounds have been reported to have anti-inflammatory and analgesic effects [7].

Cussonia barteri Seem (Araliaceae) is a mediumsized broadleaf tree, which grows up to about $10 \mathrm{~m}$. The tree grows in the savannah regions of Sub-Saharan Africa, Yemen, and has a thick trunk and hard bark [8]. The plant has greenish-white, fingerlike leaves [9]. The fruits are fleshy and turn purple to white when ripe [10]. The plant undergoes complete defoliation in the dry season. The defoliated tree has the shape of a 'cut off limb' and is thus named 'stump of an amputated limb' in Mali and Volta, 'leper's hand' in Northern Nigeria [11]. The plant is called 'Ako-sigo' in yoruba, 'Tuwon giwa' in hausa, 'Bolo Koro' in Senegal and 'Kokobidua' in Ghana [12], while the seeds are called 'jansa' seeds (Cameroun), 'Ugbaokwe' (Igbo), 'Takandagiwa' (Hausa) and 'Shigo' (Yoruba) in Nigeria [13]. C. barteri is utilized for various purposes in ethnomedicine. The whole plant and its stem bark are used as a purgative, an aphrodisiac and as external lotion in Mali [14]. The seeds are used in cooking soup in some societies [13]. Decoctions of the root and stem bark are used in menstrual pain, rheumatism, emetic, epilepsy and mental disorders [15]. The leaves, stem, root and seeds have been documented to contain fatty acids, sugars, flavonoids, saponins, steroids, phenols, tannins, glycosides and alkaloids [16, 17]. Isolated compounds from the leaves and stem bark have been elucidated [16]. The presence of these phytochemical constituents and documented ethnomedicinal use of C. barteri stimulated the need for the assessment of the leaf for antiinflammatory and analgesic effects.

\section{MATERIAL AND METHODS}

\section{Plant material}

Parts of the Cussonia barteri plant comprising leaves were obtained from Basawa area of Sabongari, Kaduna state, Nigeria in July 2016. The plant was identified and authenticated at the National Institute for Pharmaceutical Research and Development (NIPRID) and a herbarium sample (NIPRD/H/6995) was deposited for future reference.

\section{Extraction}

The leaves were sundried over a period of one week after which it was reduced to powder form using a mechanical mill. Repetitive Soxhlet extractions were carried out with the powdered plant material $(500 \mathrm{~g})$ in 21 of $100 \%$ methanol. The mixture was filtered and concentrated using a rotary evaporator to give a percentage yield of $54.9 \%$. The resulting methanol extract was suspended in 5\% gum acacia before use.

\section{Experimental animals}

Swiss albino mice (20-30 g) and Wistar rats (150$180 \mathrm{~g}$ ) of either sexes were purchased at the Department of Pharmacology Animal House, University of Benin. They were housed in polypropylene cages, had free access to clean drinking water and pelletized feed. 
The animals were maintained under standardized environmental conditions. The handling procedures were conducted in accordance with recommended procedures of the Faculty of Pharmacy Ethical Committee on Experimental Animals (EC/FP/019/01) and followed the internationally accepted laboratory animal use and care guidelines and rules of IAEC.

\section{Drugs and chemicals}

$\lambda$-carrageenan and indomethacin (Sigma Chemical, USA), xylene (BDH Chemicals, UK), 40\% formaldehyde (Pyrex IG, Nigeria), dexamethasone (Alpha Pharma, Nigeria), acetic acid (BDH Chemicals, England), acetylsalicylic acid powder (Pyrex-IG Company, Nigeria), morphine hydrochloride (Alpha Pharma, Abuja) were used in the experiment.

\section{Acute toxicity study}

Swiss albino mice were divided into five groups of five animals each. The control group was orally administered with distilled water $(8 \mathrm{ml} / \mathrm{kg})$, while groups $2-5$ were orally administered with $0.5,1$, 2.5 and $5 \mathrm{~g} / \mathrm{kg}$ of extract suspended in $5 \%$ gum acacia, respectively [18]. The animals were observed for signs of toxicity and mortality within 24 hours of administration. They were further observed for another two weeks for any signs of delayed toxicity.

\section{Anti-inflammatory study}

\section{Carrageenan-induced paw oedema assay}

Wistar rats (150-200 g) were divided into five groups of five animals each. Groups 1, 2 and 3 were orally administered with 100,200 and $400 \mathrm{mg} / \mathrm{kg}$ of the extract. Group 4 received indomethacin $(10 \mathrm{mg} / \mathrm{kg})$ suspended in $5 \%$ gum acacia (p.o.), while the control group received $5 \%$ gum acacia $(3 \mathrm{ml} / \mathrm{kg})$ p.o. The basal paw thickness of the right hind paw was measured with a vernier caliper. After $1 \mathrm{~h}$ of pretreatment, $100 \mu \mathrm{l}$ of $0.1 \% w / v$ carrageenan suspension in normal saline was injected into the sub plantar tissue of the right hind paw. Paw thickness was measured using a Vernier caliper at hourly intervals for $5 \mathrm{~h}[19,20]$.

\section{Formalin-induced arthritis test}

The modified method of Hosseinzadeh and Younes
[21] was applied for this study. Wistar rats (150$200 \mathrm{~g}$ ) were allotted into five groups of five animals each. There groups were treated as previously described above. One hour after pretreatment, inflammation was induced in all groups by subaponeurotic injection of $100 \mu \mathrm{l}$ of $2 \% \mathrm{w} / \mathrm{v}$ formalin in the right hind paw of the animals; inflammation was also induced on the third day. The inflamed right paw thickness was measured daily for 5 days using the vernier caliper.

\section{Xylene-induced ear oedema assay}

The method of Akindele and Adeyemi [22] was used with slight modifications. Five groups of 5 mice each were treated with the extract $(100,200$ and $400 \mathrm{mg} / \mathrm{kg}$ p.o.), dexamethasone ( $1 \mathrm{mg} / \mathrm{kg}$ i.p.) and $5 \%$ gum acacia ( $10 \mathrm{ml} / \mathrm{kg}$ p.o.). Thirty minutes after pretreatment, oedema was induced by applying $30 \mu \mathrm{l}$ of xylene into the inner surface of the right ear. The left ear was considered as control. After fifteen minutes, the animals were sacrificed under chloroform anaesthesia and both ears were removed and weighed [6]. The mean of the difference between the right and left ears was calculated using the following formula:

$$
\% \text { inhibition }=100\left(\mathrm{Vc}-\frac{\mathrm{Vt}}{\mathrm{Vc}}\right)
$$

where $V_{c}$ represents difference in weight of ear in control and $V_{t}$ difference in weight of ear in group treated with standard/extract.

\section{Analgesic study}

\section{Acetic acid-induced writhing in mice}

The method of Koster et al. [23] was used for this test. The mice were randomly assigned into five groups of five animals each. The extract (100, 200 and $400 \mathrm{mg} / \mathrm{kg}$, p.o.), and acetylsalicylic acid $(100 \mathrm{mg} / \mathrm{kg}$ p.o.) suspended in $5 \%$ gum acacia and $5 \%$ gum acacia (control group) $(10 \mathrm{ml} / \mathrm{kg}$ p.o.) were administered to groups 1 to 5, respectively. One hour after pre-treatments, $10 \mathrm{ml} / \mathrm{kg}$ of $0.6 \% \mathrm{v} / \mathrm{v}$ acetic acid i.p. was administered to all groups. The amount of writhes was immediately recorded every 5 minutes for a period of 30 minutes [4]. Percentage inhibition of writhes in comparison to control group was calculated as:

$\%$ inhibition $=$ 


\section{Hot plate test}

The modified method of Eddy and Leimbach [24] was used to evaluate the reaction times to pain. Animals were allotted into five groups of five mice. The extract $(100,200$ and $400 \mathrm{mg} / \mathrm{kg}$ p.o.) suspended in $5 \%$ gum acacia, $5 \%$ gum acacia (control group) (10 ml/kg p.o.) and morphine ( $2 \mathrm{mg} / \mathrm{kg}$, s.c.), were administered to groups 1 to 5 , respectively. The animals were acclimatized for 30 minutes on the hot plate apparatus; thereafter, the temperature of the hot plate was set at $55 \pm 1^{\circ} \mathrm{C}$. The latency, defined as the reaction time of each mouse (licking of the forepaws or jumping response) was recorded. Pretreatment reaction for each mouse was determined and 30 seconds was set as the post-treatment cut off time. Reaction time was recorded at time intervals of $0,30,60,90$, and 120 minutes post treatment.

\section{Tail flick test}

In this model [25], a radiant heat automatic tail flick analgesiometer (Ugo Basile) was used. Five groups of 5 rats each were treated with the extract (100, 200 and $400 \mathrm{mg} / \mathrm{kg}$ p.o.) suspended in 5\% gum acacia, morphine $(2 \mathrm{mg} / \mathrm{kg}$ s.c.) and $5 \%$ gum acacia (control group) (10 ml/kg p.o.). One hour after pretreatments, the tail tips $(1-2 \mathrm{~cm})$ of the animals were placed over the radiant heat source and the tail withdrawal from the heat was taken as the end point. The reaction time (sec) of each rat in each group was determined at $0,30,60,90$ and 120 minutes. A cutoff time of 30 seconds was set to avoid tail trauma.

\section{Statistical analysis}

All data were expressed as mean \pm SEM. Data were analyzed by one way analysis of variance (ANOVA) followed by Dunnet post hoc test (Graphpad Prism
6, San Diego, USA). Results were considered statistically significant at $p<0.05$.

\section{RESULTS}

\section{Acute toxicity of C. barteri}

There were no toxic or adverse effects at all doses $(0.5,1,2.5$ and $5 \mathrm{~g} / \mathrm{kg})$ after $24 \mathrm{hrs}$. No signs of delayed toxicity and mortality were recorded at all doses after two weeks after treatment (tab. 1).

\section{Anti-inflammatory effects of C. barteri}

\section{Carrageenan-induced paw oedema assay}

In this model (fig. 1), the extract ( 200 and $400 \mathrm{mg} / \mathrm{kg}$ ) significantly $(p<0.01)$ inhibited paw edema for three hours (1-3 h), however $100 \mathrm{mg} / \mathrm{kg}$ dose of the extract only significantly $(p<0.01)$ inhibited paw edema in the first hour, compared with the negative control.

\section{Xylene-induced ear oedema}

The extract (100, 200 and $400 \mathrm{mg} / \mathrm{kg}$ ) inhibited xylene-induced edema significantly with percentage values of $47.71 \%, 67.61 \%$ and $65.63 \%$ respectively (tab. 2). The inhibitory effect at doses of 200 and $400 \mathrm{mg} / \mathrm{kg}$ was higher than that of dexamethasone, with an inhibition of $59.15 \%$.

\section{Formalin-induced arthritis}

Table 3 shows the effect of the extract on formalininduced arthritis. The extract did not significantly inhibit formalin-induced arthritis.

Table 1

Acute oral toxicity of C. barteri in mice

\begin{tabular}{lllllll} 
Group & Log Dose & Diarrhea & Sedation & Tremor & Writhing & Mortality \\
\hline Control & - & $0 / 5$ & $0 / 5$ & $0 / 5$ & $0 / 5$ & $0 / 5$ \\
\hline CB $500 \mathrm{mg} / \mathrm{kg}$ & 2.699 & $0 / 5$ & $0 / 5$ & $0 / 5$ & $0 / 5$ & $0 / 5$ \\
\hline CB $1000 \mathrm{mg} / \mathrm{kg}$ & 3.000 & $0 / 5$ & $0 / 5$ & $0 / 5$ & $0 / 5$ & $0 / 5$ \\
\hline CB $2500 \mathrm{mg} / \mathrm{kg}$ & 3.398 & $0 / 5$ & $0 / 5$ & $0 / 5$ & $0 / 5$ & $0 / 5$ \\
\hline CB $5000 \mathrm{mg} / \mathrm{kg}$ & 3.699 & $0 / 5$ & $1 / 5$ & $0 / 5$ & $0 / 5$ & $0 / 5$ \\
\hline
\end{tabular}

Control: 5\% gum acacia; CB: Cussonia barteri 

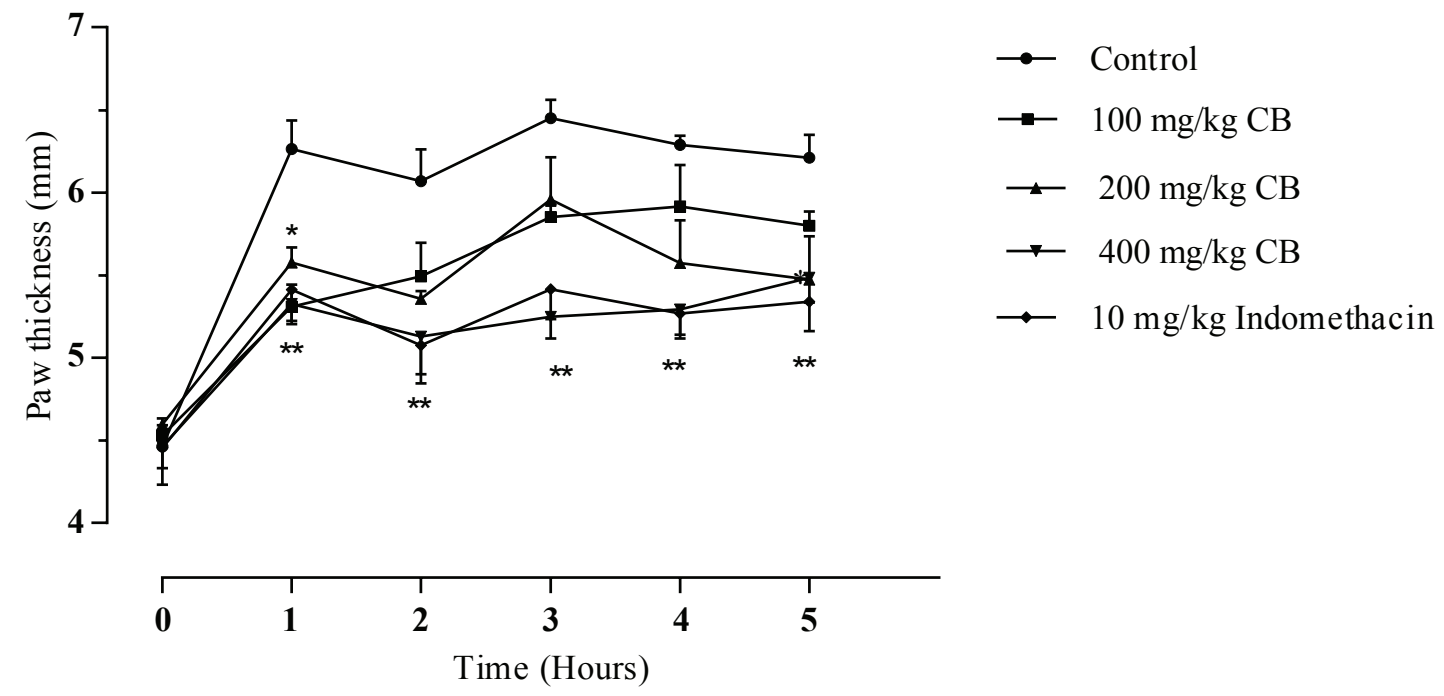

Figure 1

Effect of methanol extract of C. barteri on carrageenan-induced paw edema in rats. $\mathrm{CB}-$ Cussonia barteri. ${ }^{\star} p<0.05,{ }^{*} p<0.01$, when compared to the control (5\% gum acacia, $3 \mathrm{ml} / \mathrm{kg}$ ).

Table 2

Effect of methanol leaf extract of Cussonia barteri on xylene-induced ear edema

\begin{tabular}{lcllcl} 
Treatment & Dose $[\mathrm{mg} / \mathrm{kg}]$ & Weight of right ear $[\mathrm{mg}]$ & Weight of left ear $[\mathrm{mg}]$ & Difference $[\mathrm{mg}]$ & \% Inhibition \\
\hline Control & $3 \mathrm{ml} / \mathrm{kg}$ & $55.60 \pm 6.62$ & $34.30 \pm 2.26$ & $21.30 \pm 4.36$ & - \\
\hline $\mathrm{CB}$ & 100 & $41.23 \pm 1.97$ & $30.10 \pm 2.45$ & $11.13 \pm 0.48^{*}$ & 47.7 \\
\hline $\mathrm{CB}$ & 200 & $33.80 \pm 0.72$ & $26.90 \pm 2.20$ & $6.90 \pm 1.48^{*}$ & 67.61 \\
\hline $\mathrm{CB}$ & 400 & $48.85 \pm 10.45$ & $41.53 \pm 7.00$ & $7.32 \pm 3.45^{*}$ & 65.63 \\
\hline Dexamethasone & 1 & $35.28 \pm 4.77$ & $26.58 \pm 2.07$ & $8.7 \pm 2.70^{*}$ & 59.15 \\
\hline
\end{tabular}

Values are mean \pm S.E.M. ${ }^{*} p<0.05$, as compared to the control. $\mathrm{n}=5$ for each group. $\mathrm{CB}-$ Cussonia barteri

\section{Table 3}

Effect of methanol leaf extract of Cussonia barteri on formalininduced arthritis

\begin{tabular}{llll} 
Treatment & $\begin{array}{l}\text { Dose } \\
{[\mathrm{mg} / \mathrm{kg}]}\end{array}$ & $\begin{array}{l}\text { Paw thickness on } \\
\text { day } 5[\mathrm{~mm}]\end{array}$ & \% Inhibition \\
\hline Control & $3 \mathrm{ml} / \mathrm{kg}$ & $7.04 \pm 0.23$ & - \\
\hline $\mathrm{CB}$ & 100 & $6.48 \pm 0.07$ & 7.95 \\
\hline $\mathrm{CB}$ & 200 & $6.85 \pm 0.39$ & 2.70 \\
\hline $\mathrm{CB}$ & 400 & $6.79 \pm 0.25$ & 3.55 \\
\hline Indomethacin & 5 & $5.93 \pm 0.36^{*}$ & 15.76 \\
\hline
\end{tabular}

Values are mean \pm S.E.M. ${ }^{\star} p<0.05$, as compared to the control. $\mathrm{n}=5$ for each group. $\mathrm{CB}-$ Cussonia barteri

\section{Analgesic effect of C. barteri}

\section{Acetic acid induced writhing}

The extract at $400 \mathrm{mg} / \mathrm{kg}$, significantly $(p<0.05)$ decreased the number of writhes compared to the control at the $25^{\text {th }}$ and $30^{\text {th }}$ minute with a $27.36 \%$ inhibition (fig. 2).

\section{Hot plate test}

In this model, the extract did not increase the reaction times in the animals (tab. 4).

\section{Tail flick test}

The extract did not produce any significant $(p>0.05)$ increase in reaction times when compared to the control (tab. 5). 


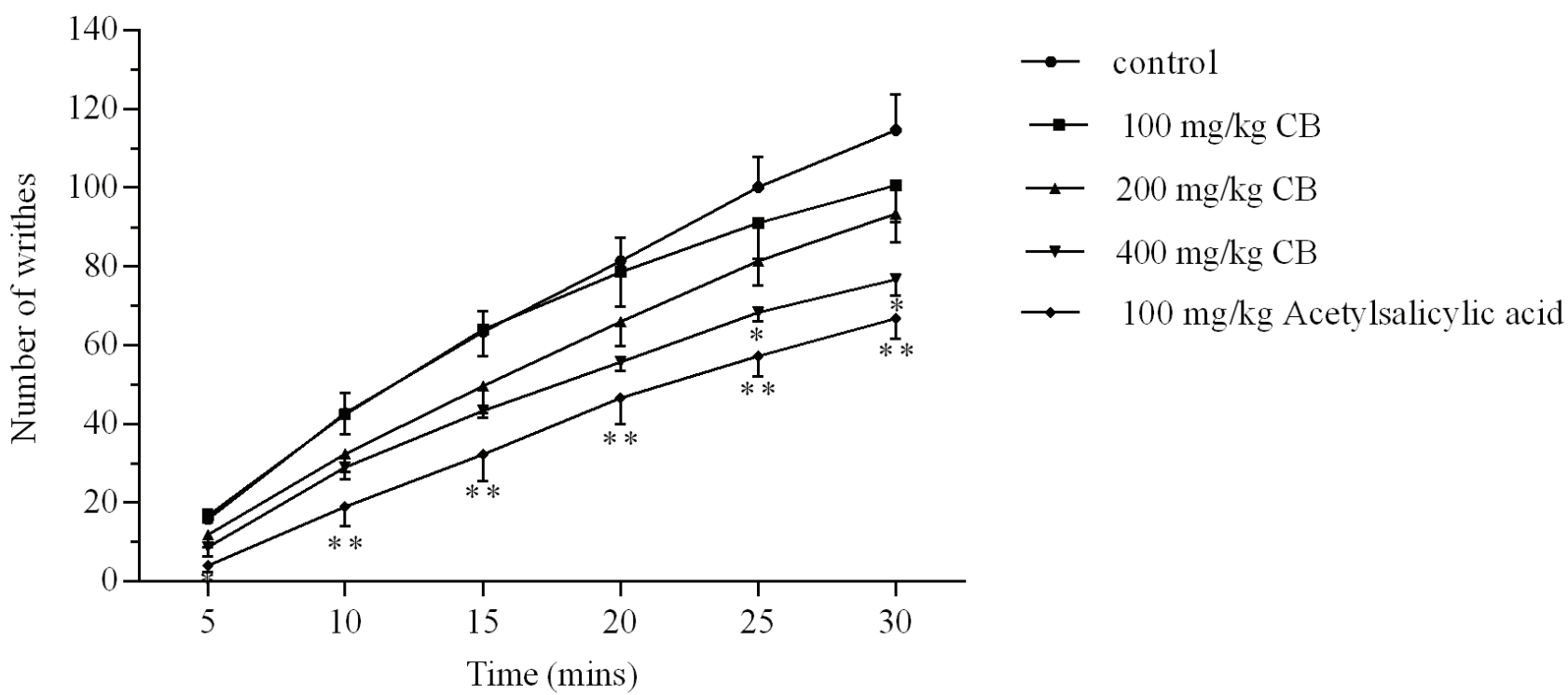

Figure 2

Effect of methanol extract of $C$. bateri on acetic acid induced mouse writhing. ${ }^{*} p<0.05,{ }^{*} p<0.01$, when compared to control group (5\% gum acacia, $10 \mathrm{ml} / \mathrm{kg}) . \mathrm{CB}-$ Cussonia bateri

Table 4

Effect of methanol extract of C. barteri on hot plate in mice

\begin{tabular}{llccccc}
\multirow{2}{*}{ Groups } & \multirow{2}{*}{ Dose $[\mathrm{mg} / \mathrm{kg}]$} & \multicolumn{5}{c}{ Reaction times } \\
\cline { 3 - 7 } & & $0 \mathrm{~min}$ & $30 \mathrm{~min}$ & $60 \mathrm{~min}$ & $90 \mathrm{~min}$ & $120 \mathrm{~min}$ \\
\hline Distilled water & - & $4.20 \pm 0.50$ & $3.58 \pm 0.59$ & $4.42 \pm 0.39$ & $4.53 \pm 0.67$ & $4.24 \pm 0.12$ \\
\hline $\mathrm{CB}$ & 100 & $3.42 \pm 0.44$ & $3.40 \pm 0.51$ & $4.22 \pm 0.59$ & $6.78 \pm 0.57$ & $6.02 \pm 0.95$ \\
\hline $\mathrm{CB}$ & 200 & $3.42 \pm 1.05$ & $4.93 \pm 0.39$ & $5.23 \pm 0.78$ & $4.50 \pm 1.15$ & $6.52 \pm 0.68$ \\
\hline $\mathrm{CB}$ & 400 & $2.78 \pm 0.21$ & $6.42 \pm 1.35$ & $5.50 \pm 0.58$ & $7.00 \pm 0.58$ & $6.80 \pm 1.06$ \\
\hline Morphine & 1 & $3.43 \pm 0.52$ & $11.77 \pm 2.17^{*}$ & $11.43 \pm 1.37^{*}$ & $10.00 \pm 2.29^{*}$ & $8.17 \pm 3.60$ \\
\hline
\end{tabular}

Values are mean \pm S.E.M. ${ }^{\star} p<0.05$, as compared to the control ( $5 \%$ gum acacia, $5 \mathrm{ml} / \mathrm{kg}$ ). CB - Cussonia barteri

Table 5

Effect of methanol extract of C. barteri on tail flick in mice

\begin{tabular}{|c|c|c|c|c|c|c|}
\hline \multirow{2}{*}{ Groups } & \multirow{2}{*}{ Dose $[\mathrm{mg} / \mathrm{kg}]$} & \multicolumn{5}{|c|}{ Reaction times } \\
\hline & & $0 \mathrm{~min}$ & $30 \mathrm{~min}$ & $60 \mathrm{~min}$ & $90 \mathrm{~min}$ & $120 \mathrm{~min}$ \\
\hline Distilled water & - & $4.90 \pm 0.07$ & $5.35 \pm 0.89$ & $4.65 \pm 0.60$ & $5.78 \pm 0.52$ & $4.15 \pm 0.52$ \\
\hline $\mathrm{CB}$ & 100 & $5.28 \pm 0.81$ & $5.68 \pm 1.24$ & $4.56 \pm 0.32$ & $5.56 \pm 0.69$ & $5.60 \pm 0.87$ \\
\hline $\mathrm{CB}$ & 200 & $4.22 \pm 0.46$ & $4.28 \pm 1.15$ & $5.23 \pm 1.03$ & $5.90 \pm 0.76$ & $4.83 \pm 0.11$ \\
\hline $\mathrm{CB}$ & 400 & $5.28 \pm 0.57$ & $4.00 \pm 0.61$ & $6.18 \pm 0.39$ & $6.56 \pm 1.42$ & $4.56 \pm 1.04$ \\
\hline Morphine & 2 & $4.30 \pm 0.43$ & $2.25 \pm 4.82^{* * *}$ & $12.70 \pm 3.01^{\star *}$ & $8.60 \pm 1.56$ & $10.43 \pm 2.84^{*}$ \\
\hline
\end{tabular}

Data are expressed as mean \pm SEM. ${ }^{*} p<0.05,{ }^{* *} p<0.01,{ }^{* *} p<0.001$, when compared to control (5\% gum acacia $5 \mathrm{ml} / \mathrm{kg}$ ). CB Cussonia barteri

\section{DISCUSSION}

Acute safety evaluation assesses administered doses of a substance for immediate toxic effects [26]. A previous study by Yakubu et al. [17], revealed that the ethanol leaf extract of $C$. barteri had an $\mathrm{LD}_{50}$ of above
$5000 \mathrm{mg} / \mathrm{kg}$ at acute oral doses and was reported to be safe on oral administration. This study also demonstrated that the methanol leaf extract was devoid of immediate toxic effects at all administered oral doses.

Phytochemical constituents present in medicinal plants serve as a predictive index for biological 
activity [27]. Constituents including saponins, flavonoids, phenols, alkaloids, tannins and oils have been established to possess a plethora of biological effects including analgesic, anti-microbial and antiviral effects $[6,27,28]$. The leaves of $C$. barteri have been demonstrated in previous studies to contain saponins; these saponins have been isolated with documented biological activities [29, 30].

This study assesses the anti-inflammatory and analgesic effect of the methanol leaf extract of $C$. barteri. The carrageenan-induced paw oedema is used to study acute inflammation $(<24 \mathrm{~h})$. A subcutaneous injection of $1 \%$ carrageenan in rat paw stimulates an oedema that includes an early phase $(1-3 \mathrm{~h})$ principally mediated by histamine, serotonin and a late phase ( $>4 \mathrm{~h}$ ) mainly caused by prostaglandins, nitric oxide, protease and bradykinins [31-33]. The extract significantly reduced paw sizes at the highest dose in carrageenan-induced inflammation, suggesting that the extract may be effective in acute inflammatory states. This attribute of the extract may indicate the presence of triterpene, saponins and flavonoids that have documented anti-inflammatory effects [30, 34]. The extract's ability to produce a sustained effect in both phases of the carrageenan induced inflammation may suggest the extract interferes with the activity of several mediators (such as serotonin, bradykinin, prostaglandins and histamine) involved. The extract produced similar effects in xylene-induced ear oedema. The local application of xylene into the inner ear surface of the mice stimulates acute inflammatory effects that lead to increases in the ear thickness; the increase in ear thickness is partly due to substance $\mathrm{P}$, which causes plasma extravasations and subsequent oedema [35]. The extract significantly reduced ear weights at all doses, the percentage inhibition of ear oedema by the extract $(200 \mathrm{mg} / \mathrm{kg})$ was similar to dexamethasone, which was used as a standard. This further establishes the extracts effect in acute inflammation. In contrast to this observation, the isolated quinic esters, rutin and saponins from the methanol leaf extract did not produce anti-inflammatory effect when tested against 5-lipoxygenase and cyclooxygenase-1 inhibition [29]; we suggest that the extract may possess other biological constituents that may be synergistic to its probable anti-inflammatory effect seen in this study [36].The formalin-induced arthritis test is used to evaluate substances for sub-acute antiinflammatory effect [37]. The injection of formalin into the hind paw stimulates an intense, painful and proliferative inflammatory reaction partly mediated by products of the cycloxygenase (COX) pathway and may eventually lead to deformity of the hind paw [38,
44]. The extract caused a reduction in paw sizes on the third day, this effect was not sustained as paw size significantly increased on the fourth and fifth days. This is consistent with the acute inflammatory effects of the extract observed in this study from carrageenan and xylene models of inflammation; the involvement of products of the COX pathway may have partially explained the observed acute effects of the extract in the formalin test [44].

The acetic acid-induced writhing assay is one of the most commonly applied tests used to screen substances for peripheral analgesic effect $[23,39]$. The intraperitoneal administration of acetic acid irritates resident cells leading to the production of endogenous intermediaries that initiates an inflammatory response which results in the stimulation of peripheral nociceptors [40]. The extract significantly reduced mouse writhing at the highest dose only. The extracts probable effects on prostaglandin activity as reported from anti-inflammatory studies may have also partly resulted in the decrease in the number of writhes as prostaglandins play a role in the acetic acid induced writhing test [42]. Earlier reports by Dubois and his colleagues revealed that the stem bark of C. barteri possessed sedative activity and they attributed this sedative effect to the presence of saponins. We suggest that the saponins present in the leaves may have also contributed to the reduction of writhes caused by extract, as substances with sedative and muscle relaxant effects can also reduce the number of observed writhes in this model $[41,43]$. The hot plate test employs thermal stimuli and is a simple test for assessing substances for centrally mediated analgesic effect. This test involves the introduction of a mice into a cylindrical metallic plate that is heated by a thermode [24]. Higher spinal mechanisms and brain centres are involved in integrating responses associated with the hot plate test; these responses are attenuated by opioids and substances with centrally mediated analgesic effect [43]. The extract did not increase reaction times at all doses significantly, suggesting the extract lacked centrally mediated analgesic effects. However, there was an observed increase in the reaction times (time taken for the mice to lick the paw) at all doses of the extract as the experiment progressed; NSAIDS are known to increase the period taken for the animal to lick its paw in this model and this may be as a result of COX inhibition, a probable effect of the extract [43]. The tail flick test is another test used to screen substances for centrally mediated analgesic effect. All doses of the extract had no significant effect on tail flick reaction times. This further affirms the extracts lack of centrally mediated analgesic effect. 


\section{CONCLUSION}

The results from this study show that the leaves of C. barteri possess dose dependent acute antiinflammatory and peripherally mediated analgesic effects. Further mechanistic studies may need to be carried out to assess the probable mechanism(s) of the leaf extract.

Conflict of interest: Authors declare no conflict of interest.

\section{REFERENCES}

1. Medzhitov R. Origin and physiological roles of inflammation. Nature 2008, 454(7203):428-35. doi: http://dx.doi.org10.1038/nature07201

2. Punchard NA, Whelan CJ, Adcock I. J Inflamm. 2004;1:1. doi: http://dx.doi.org/10.1186/1476-9255-1-1

3. Adedapo AA, Falayi OO, Oyagbemi AA. Evaluation of the analgesic, anti-inflammatory, anti-oxidant, phytochemical and toxicological properties of the methanolic leaf extract of commercially processed Moringa oleifera in some laboratory animals. J Basic Clin Physiol Pharmacol 2015; 26(5):491-9. doi: http://dx.doi.org/ 10.1515/jbcpp-2014-0105

4. Igbe I, Ayinde BA, Izuchukwu A. Anti-inflammatory and analgesic effects of the methanol stem bark extract of Brachystegia eurycoma Harms (Fabaceae). Eur J Med Plants 2012; 2(4):356-365. doi: http://dx.doi.org/10.9734/EJMP/2012/1599

5. Heidari MR, Foroumadi A, Noroozi H, Samzadeh-Kermani A, Azimzadeh BS. Study of the anti-inflammatory and analgesic effects of novel rigid benzofuran-3, 4-dihydroxy chalcone by formalin, hot-plate and carrageenan tests in mice. Pak J Pharm Sci 2009; 22(4):395-401. doi: http:// dx.doi.org/10.1111/j.1749-6632.2009.04904

6. Igbe I, Ching FP, Eromon A. Anti-inflammatory activity of aqueous fruit pulp extract of Hunteria umbellata K. Schum in acute and chronic inflammation. Acta Pol Pharm - Drug Res 2010; 67(1):81-85.

7. Cavalcante-Silva LH, Falcão MA, Vieira AC, Viana MD, de Araújo-Júnior JX, et al. Assessment of mechanisms involved in antinociception produced by the alkaloid caulerpine. Molecules 2014; 19(9):14699-14709. doi: http://dx.doi. org/10.3390/molecules190914699

8. Burkill $\mathrm{H}$. The useful plants of west tropical Africa. Kew, Royal Botanical Gardens. 2nd ed. The Whitefriars Press Limited, London, 1985.

9. Keay RNJ, Onochie CFA, Standfield DP. Nigerian trees by Federal Department of Forest Research in Nigeria. Offset Lithography of the University Press, Nigeria 1964:65-67.

10. Zanoni TA, Farjon A. World checklist and bibliography of conifers. Brittonia 1999; 51:76. doi: http://dx.doi.org/10.2307/2666560

11. Kerharo J, Bouquet A. Medicinal and toxic plants of Côte d'Ivoire-Upper Volta: study mission of the indigenous pharmacopoeia in AOF. Paris: Vigot. 1950; 297. doi: http://dx.doi.org/www.documentation.ird.fr/hor/fdi:01281

12. Irvine FR. Plants of the Gold Coast. 1930; 6(23):45.

13. Nwokonkwo DC. Physicochemical and phytochemical studies of the constituents of the seed of Cussonia barteri (Jansa Seeds). Am J Sci Ind Res 2013; 4(4):414-419. doi: http://dx.doi. org/10.5251/ ajsir.2014.5.1.7.12

14. Diallo A, Marston C, Terreaux Y, Toure BS, Paulsen, Hostettmann K. Screening of Malian medicinal plants for antifungal, larvicidal, molluscicidal, antioxidant and radical scavenging activities. Phytother Res 2001; 15(5):401-406. doi: http://dx.doi.org/10.1002/ptr.738

15. Adeniji K, Amusan O, Dlamini P, Enow-Orock E. Traditional medicine and pharmacopoeia contribution to ethnobotanical and floristic studies in Swaziland. The Scientific, Technical and Research Commision of the Organisation of African Unity (OAU/STRC) 2000; 23(4):207.

16. Chazan J. Répartition des sapogénines triterpéniques dans quelques genres d’araliacées de Madagascar. Phytochemistry 1971; 5(76):73-87. doi: http://dx.doi.org/10.1016/S0031-9422(00)97204-2

17. Igbe I, Edosuyi O, Okhuarobo A. Harnessing the medicinal properties of Cussonia barteri Seem. (Araliaceae) in drug development. A review. 
Herba Pol 2018; 64(3):50-61. doi: http://dx.doi. org/10.2478/hepo-2018-0018

18. Miller L, Tainter M. Estimation of the $\mathrm{ED}_{50}$ and its error by means of logarithmic-probit graph paper. Proc Soc Exp Biol Med. 1944 57(2):261-264. doi: http://dx.doi.org/10.3181/00379727-57-14776

19. Winter C, Risley E, Nuss G. Carrageenan-induced edema in hind paw of the rat as an assay for antiinflammatory drugs. Biol Med 1962; 111(3):544-547. doi: http://dx.doi.org/10.3181\% 2F00379727-111-27849

20. Thambi P, Kuzhivelil B, Sabu M, Jolly CI. Antioxidant and anti-inflammatory activities of the flowers of Tabernaemontana coronaria (L.) R. B. Indian J Pharm Sci 2006; 68(3):352-355. doi: http:// dx.doi.org/10.4103/0250-474X.26675

21. Hosseinzadeh H, Younesi H. Antinociceptive and anti-inflammatory effects of Crocus sativus $\mathrm{L}$. stigma and petal extracts in mice. BMC Pharmacol 2002; 2:7. doi: http://dx.doi.org/10.1186/14712210-2-7

22. Akindele A, Adeyemi O. Antiinflammatory activity of the aqueous leaf extract of Byrsocarpus coccineus. Fitoterapia. 2007; 78(1):25-28. doi: http:// dx..doi.org10.1016/j.fitote.2006.09.002

23. Koster R, Anderson M, De Beer E. Acetic acid for analgesic screening. Fed Proc 1959; 18:412-430.

24. Eddy NB, Leimbach D. Synthetic analgesics. II. Dithienylbutenyl- and dithienylbutylamines. J Pharmacol Exp 1953; 107(3):385-393.

25. D'Amour FE, Smith DL. A method fron determining loss of pain sensation. J Pharmacol 1941; 27:74-79.

26. Mir AH, Sexena M, Malla MY. An acute oral toxicity study of methanolic extract from Tridex procumbens in Sprague Dawley Rats as per OECD guidelines. Asian J Plant Sci Res. 2013; 39(1):16-20.

27. Geetha TS, Geetha N. Phytochemical screening, quantitative analysis of primary and secondary metabolites of Cymbopogan citratus (DC) Stapf leaves from Kodaikanal hills Tamilnadu. Int J Pharm Tech 2014 (6):521-529.
28. Coker ME, Emikpe BO, Adeniyi BA, Budale BA. The anti-inflammatory potential, heamatological and histological changes induced in rats due to the administration of methanolic extracts of Ficus thonningii leaves. Afr J Pharm Pharmacol 2009; 3(5):273-276.

29. Papajewski S, Volger B, Conrad J, Klaber I, Roos $\mathrm{G}$, Walter CU, et al. Isolation from Cussonia barteri of 1'-O-chlorogenoylchlorogenic acid and 1'-chlorogenoylneochlorogenic acid, a new type of quinic acid esters. Planta Med 2001; 67(8):732736. doi: http://dx.doi.org/10.1055/s-2001-18338

30. Dubois MA, Ilyas M, Wagner H. Cussonosides $\mathrm{A}$ and $\mathrm{B}$, two triterpene-saponins from Cussonia barteri. Planta Med 1986; 52(2):80-83. doi: http:// dx.doi. org/10.1055/s-2007-969084

31. Mccarson KE. Models of inflammation : Carrageenan- or complete Freund's adjuvant (CFA)-induced edema and hypersensitivity in the rat. Curr Protoc Pharmacol 2015; 70(1):1-9. doi: http:// dx.doi.org/10.1002/0471141755.ph0504s70

32. Alam B, Akter F, Parvin N, Pia RS, Akter S, et al. Antioxidant, analgesic and anti-inflammatory activities of the methanolic extract of Piper betle leaves. Avicenna J Phytomed 2013; 3(2):112-125.

33. Abotsi WK, Lamptey SB, Afrane S, Boakye-Gyasi E, Umoh RU, Woode E. An evaluation of the antiinflammatory, antipyretic and analgesic effects of hydroethanol leaf extract of Albizia zygia in animal models. Pharm Biol 2017; 55(1):338-348. doi: http//dx.doi.org/10.1080/13880209.2016.1262434

34. Iwueke AV, Nwodo OF, Okoli CO. Evaluation of the anti-inflammatory and analgesic activities of Vitex doniana leaves. Afr J Biotech 2006; 5(20):1929-1935.

35. Eddouks M, Chattopadhyay D, Zeggwagh NA. Animal models as tools to investigate antidiabetic and anti-inflammatory plants. Evid Based Complement Alternat Med 2012; 1-14. doi: http:// dx.doi.org/10.1155/2012/142087

36. Rasoanaivo P, Wright CW, Willcox ML, Gilbert B. Whole plant extracts versus single compounds for the treatment of malaria : synergy and positive interactions. Malar J 2011; 10(1):1-12. doi: http://dx.doi.org/10.1186/1475-2875-10-S1-S4 
37. Shikha P, Latha PG, Suja SR, Anuja GI, Shyamal S, Shine VJ, et al. Anti-inflammatory and analgesic activity of Barringtonia racemosa Roxb. fruits. Indian J Nat Prod Res 2010; 1:356-361. doi: http://dx.doi. org/nopr.niscair.res.in/handle/123456789/10281

38. Wheeler-Aceto AH, Cowan A. Neurogenic and tissue mediated components of formalin-induced oedema. Agents Actions Inflamm Res 1991; 34(1-2):264-269. doi: http://dx.doi.org/10.1007/ BF01993299

39. Sulaiman MR, Zakaria ZA, Bujarimin AS, Somchit MN, Israf DA, Moin S. Evaluation of Moringa oleifera aqueous extract for antinociceptive and anti-inflammatory activities in animal models. Pharm Biol 2008; 46(12):838-845. doi: http:// dx.doi.org/10.1080/13880200802366710

40. Ribeiro CF, Vale RA, Thomazzi SM, Paschoalato $\mathrm{AB}$, Poole S, Ferreira SH. Involvement of resident macrophages and mast cells in the writhing nociceptive response induced by zymosan and acetic acid in mice. Eur J Pharmacol 2000;
387(1):111-118. doi: http://dx.doi.org/10.1016/ S0014-2999(99)00790-6

41. Elisabetsky A, Amador E, Albuquerque TA, Nunes RR, Carvalho DS. Analgesic activity of Psychotria colorata (Wild ex R. \& S.) Muell Arg alkaloids. J Ethnopharmacol 1995; 48(2):77-83. doi: http:// dx.doi.org/10.1016/0378-8741(95)01287-N

42. Alam B, Hossain S, Habib R, Ria J. Antioxidant and analgesic activities of Lannea coromandelica Linn. bark extract. Int J Pharmacol 2012; 8(4): 224-233. doi: http://dx.doi.org/10.3923/ijp.2012.224.233

43. Le Bars, Gozariu M, Cadden SW. Animal models of nociception. Pharmacol Rev 2001; 53(4): 597-652.

44. Mendoza S, Noa M, Valle M, Mendoza N, Mas R. Effects of D-002 on formaldehyde-induced osteoarthritis in rats. IOSR J Pharm 2013; 3(7):9-12. 